\title{
Three examples where the specific surface area of snow increased over time
}

\author{
F. Domine ${ }^{1}$, A.-S. Taillandier ${ }^{1}$, A. Cabanes ${ }^{1}$, T. A. Douglas ${ }^{2}$, and M. Sturm ${ }^{2}$ \\ ${ }^{1}$ Laboratoire de Glaciologie et Géophysique de l'Environnement, Université Joseph Fourier, BP 96, 38402 Saint-Martin \\ d'Hères Cedex, France \\ ${ }^{2}$ US Army Cold Regions Research and Engineering Laboratory, P.O. Box 35170, Fort Wainwright, Alaska 99703-0170, USA
}

Received: 12 June 2008 - Published in The Cryosphere Discuss.: 11 August 2008

Revised: 23 February 2009 - Accepted: 23 February 2009 - Published: 16 March 2009

\begin{abstract}
Snow on the ground impacts climate through its high albedo and affects atmospheric composition through its ability to adsorb chemical compounds. The quantification of these effects requires the knowledge of the specific surface area (SSA) of snow and its rate of change. All relevant studies indicate that snow SSA decreases over time. Here, we report for the first time three cases where the SSA of snow increased over time. These are (1) the transformation of a melt-freeze crust into depth hoar, producing an increase in SSA from 3.4 to $8.8 \mathrm{~m}^{2} \mathrm{~kg}^{-1}$. (2) The mobilization of surface snow by wind, which reduced the size of snow crystals by sublimation and fragmented them. This formed a surface snow layer with a SSA of $61 \mathrm{~m}^{2} \mathrm{~kg}^{-1}$ from layers whose SSAs were originally 42 and $50 \mathrm{~m}^{2} \mathrm{~kg}^{-1}$. (3) The sieving of blowing snow by a snow layer, which allowed the smallest crystals to penetrate into open spaces in the snow, leading to an SSA increase from 32 to $61 \mathrm{~m}^{2} \mathrm{~kg}^{-1}$. We discuss that other mechanisms for SSA increase are possible. Overall, SSA increases are probably not rare. They lead to enhanced uptake of chemical compounds and to increases in snow albedo, and their inclusion in relevant chemical and climate models deserves consideration.
\end{abstract}

\section{Introduction}

The snow cover is an interface that probably has one of the highest impacts on the exchanges of energy and chemical species between the atmosphere and the surface of the Earth (Domine et al., 2008). One crucial snow physical variable relevant to these processes is its specific surface area

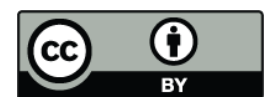

Correspondence to: F. Domine (florent@lgge.obs.ujf-grenoble.fr)
(SSA), defined as the surface area accessible to gases per unit mass (Legagneux et al., 2002). The SSA is closely related to the surface $(S)$ to volume $(V)$ ratio of snow crystals used in models that describe the interactions between snow and optical radiation (Warren, 1982; Kokhanovsky and Zege, 2004). If snow crystals are assumed to be spheres, then $\mathrm{SSA}=S / \rho V=3 /(\rho r)$, where $\rho$ is the volumic mass of ice and $r$ the radius of the spheres representing the snow crystals.

Because snow has a high SSA, up to $156 \mathrm{~m}^{2} \mathrm{~kg}^{-1}$ for fresh snow (Domine et al., 2007a), snow scatters light, is highly reflective and its albedo increases with increasing snow SSA (Warren, 1982; Domine et al., 2006). The high albedo of snow helps cool the Earth's surface. In current climate warming scenarios snow cover is expected to decrease (Dye, 2002; Stone et al., 2002; Pielke et al., 2004). The replacement of snow by darker surfaces (exposed vegetation, soils or ground cover) explains why polar regions are most affected by warming (Hall, 2004).

Snow is also known to adsorb chemical species such as semi-volatile organic compounds (SVOCs) in amounts proportional to snow SSA (Wania et al., 1998; Daly and Wania, 2004; Herbert et al., 2005; Domine et al., 2007b), and this affects atmospheric composition. Changes in snow SSA caused by snow metamorphism (Taillandier et al., 2007) result in exchanges of SVOCs between the atmosphere and the snow. In particular, upon snowmelt, chemical species can be released to the atmosphere, resulting in a sudden surge in their atmospheric concentrations (Daly and Wania, 2004). Species stored by the snowpack can also be released to terrestrial and marine ecosystems (Meyer et al., 2006).

Modeling these climatic and chemical processes requires the parameterization of snow SSA as a function of time. All available experimental and modeling studies have shown that snow SSA decreases with time (Cabanes et al., 2002, 2003; Legagneux et al., 2003, 2004; Legagneux and Domine, 2005;

Published by Copernicus Publications on behalf of the European Geosciences Union. 
Flanner and Zender, 2006; Taillandier et al., 2007). This is expected, since a high SSA produces a high surface energy per unit mass, which is thermodynamically unstable. This SSA decrease predicts that snow albedo and the storage capacity of adsorbed chemical species will decrease with time.

However, snow processes are not ruled by thermodynamics only and snow SSA can in principle increase, for example if energy is transferred to the snow or if water vapor is added or removed by condensation or sublimation. Even though instances of such processes resulting in SSA increases have not been reported, we have observed them on a number of occasions and detail three examples here. Their inclusion in models where snow is a component may help explain or predict processes such as the enhanced uptake of chemical species by snow or increases in snow albedo in the absence of precipitation (Liljequist, 1956; McGuffie and HendersonSellers, 1985; Pirazzini, 2004).

The three examples where the SSA of snow increased that we report here are: (1) the transformation of a melt-freeze crust into depth hoar; (2) the mobilization of surface snow by wind, which reduced the size of snow crystals by sublimation and fragmentation; (3) the sieving of blowing snow by an unperturbed snow layer, leading to the deposition of the smallest crystals inside the layer.

\section{Methods}

\subsection{Snow sampling}

The sampling procedure employed in this study has been described earlier (Hanot and Domine, 1999 and Domine et al., 2002). Briefly, a new snow pit with vertical faces was excavated for each sampling event to observe the stratigraphy and identify the layers of interest. Density was measured by weighing a horizontal core of known volume. This method has an accuracy of about $5 \%$ for layers thicker than $3 \mathrm{~cm}$. For SSA measurements, about $100 \mathrm{~cm}^{3}$ of snow was collected in a glass vial with a stainless steel spatula. The vial was immediately immersed in liquid nitrogen to stop metamorphism until its content was transferred to the SSA measurement container in a cold room at a temperature below $-15^{\circ} \mathrm{C}$. When possible, photomicrographs of the snow samples were taken under reflected light with a reflex camera fitted with bellows and a $35 \mathrm{~mm}$ macro lens.

\subsection{Measurements of the specific surface area of snow}

Snow SSA was determined by measuring the adsorption isotherm of methane at liquid nitrogen temperature $(77 \mathrm{~K})$, as detailed in Legagneux et al. (2002). A mathematical treatment was applied to the adsorption isotherm to derive the SSA. The method has a reproducibility of $6 \%$ and an accuracy better than $12 \%$ (Legagneux et al., 2002). Since the work of Legagneux et al. (2002) an experimental artifact due to $\mathrm{CH}_{4}$ adsorption on the stainless steel walls of the snow container was detected, as detailed in Domine et al. (2007a). All data presented here are corrected for this artifact.

\section{Results}

\subsection{Transformation of a melt-freeze crust into depth hoar}

The first case study occurred during the winter of 2003/2004 at the Large Animal Research Station (LARS) of the University of Alaska Fairbanks $\left(64^{\circ} 52^{\prime} \mathrm{N}, 147^{\circ} 44^{\prime} \mathrm{W}\right)$. The detailed study of the evolution of the snowpack has been presented by Taillandier et al. (2006). However they did not report the increase in SSA that we present here based on their complete data. The onset of snowpack formation took place on 25 October. The focus of this work is the snowfall of 7 November. For 2 days, it was subjected to temperatures that rose above $0^{\circ} \mathrm{C}$ (Fig. 1a), and to very light rain, resulting in the formation of an $8 \mathrm{~mm}$ thick melt-freeze crust on 9 November, which was fairly solid and looked completely impermeable to the eye. Temperatures then rapidly dropped below freezing, to reach $-37^{\circ} \mathrm{C}$ on 17 November. The SSA of that melt-freeze crust was measured on three occasions (Fig. 2), and the snow crystals were photographed each time (Fig. 3).

Initially, the melt-freeze layer consisted of large wellconnected grains. Its SSA was $3.4 \mathrm{~m}^{2} \mathrm{~kg}^{-1}$ on 11 November. In interior Alaska, thin snowpacks and cold temperatures combine to produce very large temperature gradients (Fig. 1b), that generate large upward water vapor fluxes. These favor the growth of large depth hoar crystals (Sturm and Benson, 1997; Taillandier et al., 2006) which in this case were sufficient to transform this hard impermeable layer into depth hoar. Figure 3 shows that on 27 January the layer was comprised of a mixture of depth hoar and melt-freeze crystals, with a SSA of $8.5 \mathrm{~m}^{2} \mathrm{~kg}^{-1}$. On 12 February, it was comprised mostly of depth hoar crystals, with a SSA of $8.8 \mathrm{~m}^{2} \mathrm{~kg}^{-1}$. Given the measurement reproducibility of $6 \%$, and the fact that small spatial variations in SSA may exist (Domine et al., 2002), these last 2 values are essentially identical, and consistent with observations that the terminal SSA of depth hoar in the subarctic snowpack around Fairbanks is about $8 \mathrm{~m}^{2} \mathrm{~kg}^{-1}$ (Taillandier et al., 2006). With these transformations, the cohesion and hardness of this layer decreased significantly: a $10 \mathrm{~cm}$ long slab of this layer would break under its own weight when held in the air. Until snow melt, however, it remained noticeably harder than the over- and underlying depth hoar layers.

\subsection{Remobilization of surface layers by wind}

This case study took place in February 2000 near Alert, in the Canadian high Arctic $\left(82^{\circ} 27^{\prime} \mathrm{N}, 62^{\circ} 30^{\prime} \mathrm{W}\right)$. Two snowfalls took place on 3 and 7 February, as described in Cabanes et al. (2002) and Domine et al. (2002). They consisted of small columns and bullet rosettes (Fig. 4) and had SSAs 

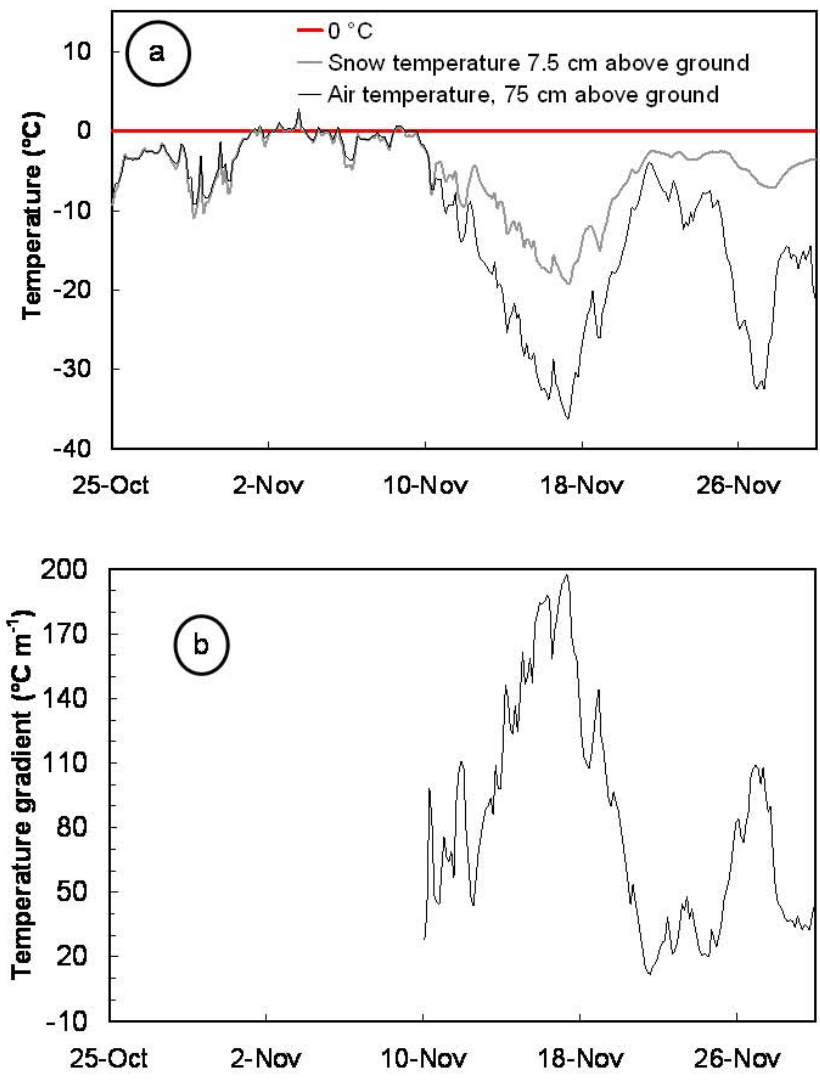

Fig. 1. (a) Temperature of snow and air at our study site near Fairbanks, Alaska, during the 2003-2004 winter. Temperatures at 7.5 and $75 \mathrm{~cm}$ above ground were almost the same until the lower sensor was buried by snow on 10 November. (b) Temperature gradient in the Alaska snowpack at the same dates, determined from differences in temperature between a sensor on the ground and a sensor $7.5 \mathrm{~cm}$ above ground. Data start when the upper sensor was covered by snow on 10 November.

measured one day after they fell of 73.4 and $140.1 \mathrm{~m}^{2} \mathrm{~kg}^{-1}$, respectively. The 7 February layer completely covered the 3 February layer and was itself subjected to the deposition of surface hoar. The SSA of both layers decreased over time. The SSA decrease of the 3 February layer is explained by crystal rounding and the disappearance of small structures under low temperature gradient conditions, while that of the 7 February layer is explained by both crystal rounding and dilution by surface hoar of lower SSA (Fig. 4). The SSA of surface hoar could not be measured, as these crystals formed too thin a layer to be collected separately. The SSA of hoar frost that was growing on antenna guy wires could nevertheless be measured, $54 \mathrm{~m}^{2} \mathrm{~kg}^{-1}$, and those crystals looked similar to those of the surface hoar.

Figure 5 shows that the SSA of both layers decreased monotonically, as expected, until 20 February. On 21 February, a wind storm started in the absence of precipitation. Both snow layers were remobilized, mixed and drifted because of

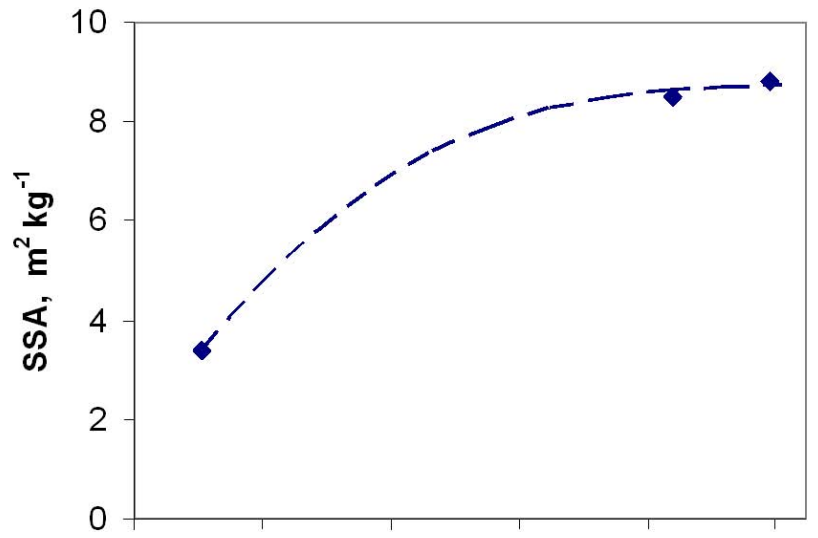

31-Oct 21-Nov 12-Dec 2-Jan 23-Jan 13-Feb

Fig. 2. Temporal evolution of the specific surface area of the meltfreeze crust studied in Alaska. The fit is our estimate, based on our observations that transformation to depth hoar is fastest early in the season, when the snowpack is thin and the temperature gradient highest.

wind action. They accumulated in spots sheltered from the wind, forming a discontinuous layer with sastrugi, over an older windpack that was now partly exposed. That newly formed discontinuous layer was sampled on 22 February and had a SSA of $61 \mathrm{~m}^{2} \mathrm{~kg}^{-1}$ (Fig. 5), higher than those of previous layers 2 days before ( 42 and $50 \mathrm{~m}^{2} \mathrm{~kg}^{-1}$ ). The new layer consisted of small rounded grains, produced by the sublimation of the small grains derived from the precipitated bullet rosettes and columns, and of rounded surface hoar crystals (Fig. 4). The SSA increase is presumably due to sublimation of grains while airborne, which reduced their size and hence their SSA, and to fragmentation, which created new surfaces.

Metamorphism, in particular induced by temperature gradients, could also produce SSA changes. However, such processes do not significantly affect SSA on timescales of a day (Taillandier et al., 2007) except for fresh snow of very high SSA. Furthermore, metamorphism would have led to a decrease in snow SSA (Taillandier et al., 2007; Cabanes et al., 2003), not to an increase as observed here.

\subsection{Sieving of blowing snow by a snow layer}

The last case study took place in February 1999 at $\mathrm{Col}$ de Porte $\left(45^{\circ} 12^{\prime} \mathrm{N}, 5^{\circ} 44^{\prime} \mathrm{E}\right)$, at an altitude of $1320 \mathrm{~m}$, just north of Grenoble in the French Alps. Sampling took place within the study site of the Centre d'Etude de la Neige (MétéoFrance). The snow layer of interest fell between 6 and 9 February, and had a thickness of $105 \mathrm{~cm}$ on 10 February. Some aspects of this snowfall are reported in Cabanes et al. (2003) but the event that resulted in the SSA increase was not mentioned. 

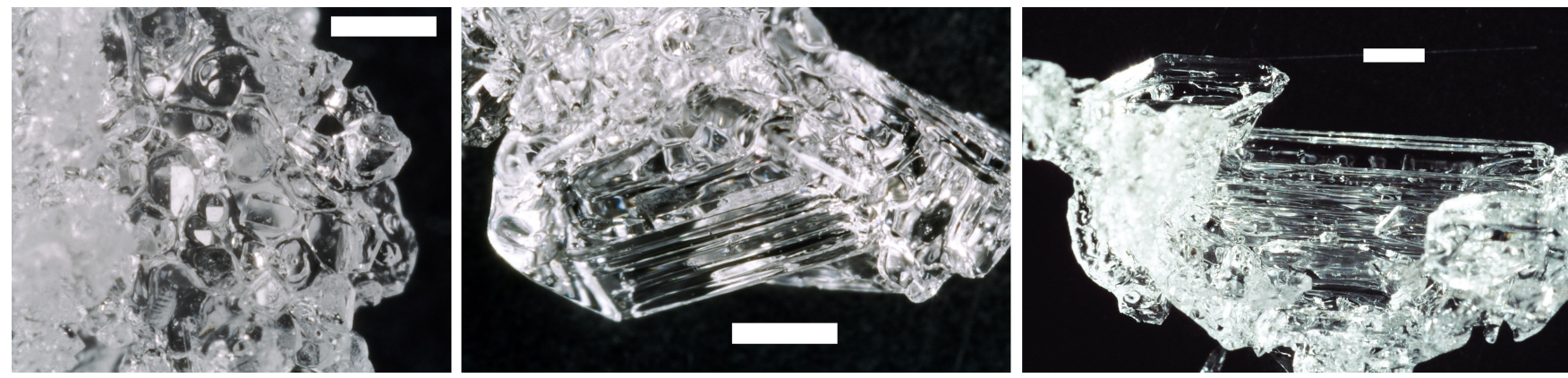

Fig. 3. Photomicrographs illustrating the formation of depth hoar from the melt-freeze crust studied in Alaska. Samples are from (left to right) 11 November 2003, 27 January 2004 and 12 February 2004. Scale bars: $1 \mathrm{~mm}$.
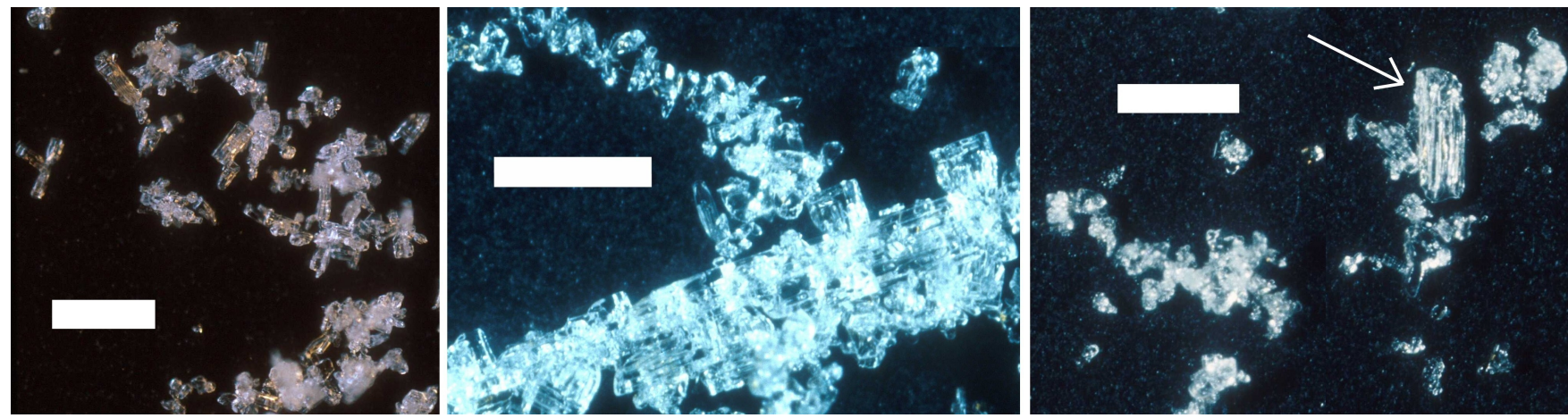

Fig. 4. Photomicrographs showing the evolution of surface snow at Alert in February 2000. From left to right : 3 February layer on 4 February, showing bullet rosettes and columns; 7 February layer on 20 February, showing very rounded precipitated crystals and well developed surface hoar crystals; both layers mixed by wind on 22 February, showing rounded and sublimated crystals. A rounded surface hoar crystal is clearly visible in the top right (arrow). Scale bars: $1 \mathrm{~mm}$.

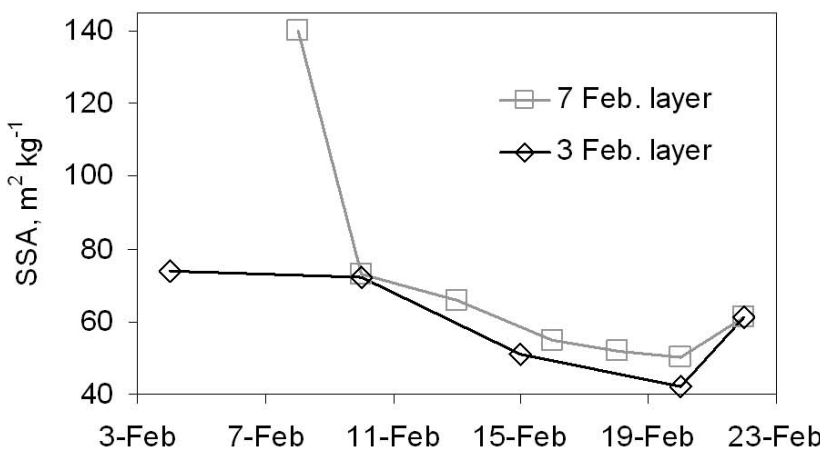

Fig. 5. Evolution of the specific surface area of two surface snow layers near Alert, Canadian Arctic. Until 20 February, the SSA decreased monotonically as expected. The 21 February windstorm remobilized the snow, grains sublimated and fragmented, leading to an SSA increase.

Figure 6 shows the evolution of the stratigraphy of the layer studied. The first sample collection occurred on the morning of 10 February. Around 16:00 LT on that day, the wind picked up and remobilized the snow. The wind lasted until the early morning of 12 February, and eroded the upper half of the snow layer. $25 \mathrm{~cm}$ of drifted snow accumulated on top of the remaining half of the layer. Figure 7 shows the SSA evolution of the two sublayers indicated in Fig. 6.

The feature of interest is the increase in SSA of sublayer (a) from 32.3 to $60.5 \mathrm{~m}^{2} \mathrm{~kg}^{-1}$. Unfortunately, no photomicrographs were taken at the time. However we provide the simplest possible explanation of the mechanisms related to this increase. We suggest that the smallest crystals of the drifting snow were trapped into sublayer (a) during the windstorm, and the addition of these small particles with a high SSA produced the observed increase. Wind blowing over the rough surface of a porous solid such as snow produces wind pumping inside the snow (Waddington et al., 1996) and ventilation can extend down to depths of several tens of $\mathrm{cm}$ (Sokratov and Sato, 2000). Wind pumping can deposit aerosol particles inside the snow, not just on its surface (Cunningham and Waddington, 1993; Waddington et al., 1993; Harder et al., 2000; Domine et al., 2004). We suggest that the snow acted like a sieve: the largest drifting crystals remained on the surface while the smallest ones could penetrate inside the snow just like aerosol particles, down to depths of several $\mathrm{cm}$. The density of sublayer (a) was $180 \mathrm{~kg} \mathrm{~m}^{-3}$ both on 10 


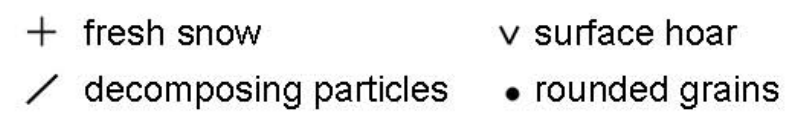

b sampling of sub-layers

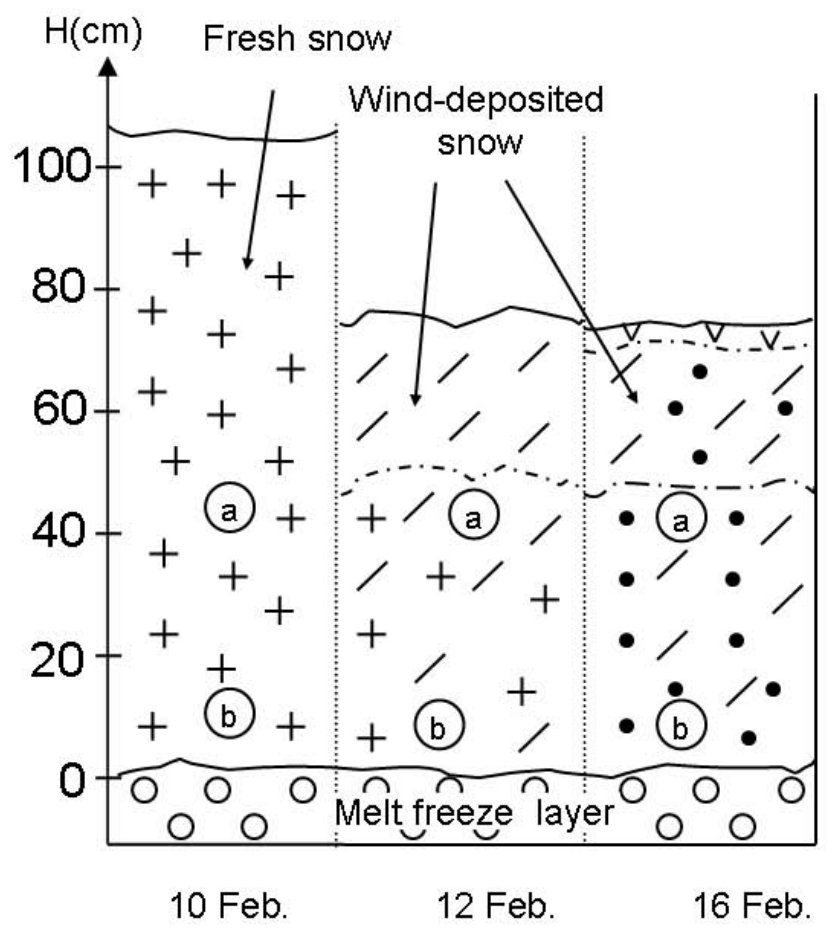

Fig. 6. Col de Porte stratigraphy in February 1999, showing sampling locations.

and 12 February, meaning that the porosity was $>80 \%$. This highly porous snow likely facilitated the transport of small crystals into the snow layer.

Other explanations are possible. There may have been a SSA discontinuity in the stratigraphy, since the snowfall consisted of distinct events. Successive samplings on either side of a discontinuity would produce SSA variations. However, visual examinations with an $8 \times$ magnifying glass revealed a fairly homogeneous layer comprised of plates, needles and columns with little or no rime. Further studies of similar cases are nevertheless needed to confirm that the sieving of blowing snow can lead to the penetration of the smallest crystals inside underlying layers.

\section{Discussion}

The SSA of snow in a closed system and under isothermal conditions decreases with time because of basic thermodynamic considerations that predict that the surface energy will decrease. Under temperature gradient conditions, the SSA

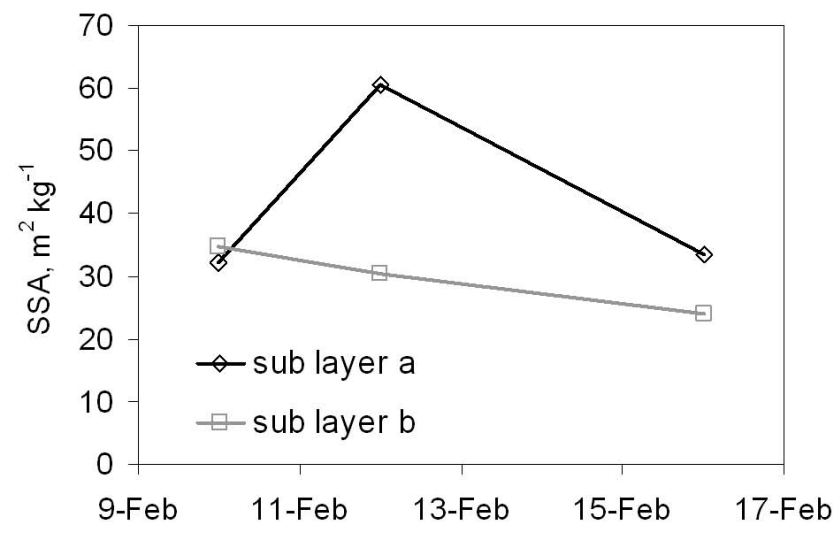

Fig. 7. Evolution of the specific surface area of two sublayers of the surface snow layers at Col de Porte, French Alps. This illustrates the SSA increase in sublayer a between 10 and 12 February 1999, thought to be due to sieving of blowing snow by sublayer a.

decrease of precipitated snow is accelerated because of more vigorous water vapor fluxes (Flanner and Zender, 2006; Taillandier et al., 2007). We show here that when a strong temperature gradient is applied to snow of low SSA, or when snow is remobilized by wind, its SSA can increase, with possible consequences on the fluxes of energy and chemical species. It is therefore of interest to discuss the frequency of such events.

\subsection{Frequency and impact of the SSA increase of melt-freeze crusts}

The transformation of a melt-freeze crust into depth hoar indicates that any snow type subjected to a sufficiently strong temperature gradient will transform into depth hoar. This is in disagreement with early studies (Akitaya, 1974; Marbouty, 1980) suggesting that depth hoar could not form in dense snow such as melt-freeze crusts. However, Sturm and Johnson (1991) reported that refrozen layers in the subarctic snowpack quickly metamorphose into depth hoar, and Sturm and Liston (2003) reported the transformation of hard wind slabs into depth hoar, confirming that dense layers can be transformed into depth hoar under extreme temperature gradients. In the case studied here, depth hoar above and below the melt-freeze crust, formed directly from precipitated crystals, had essentially the same SSA, around $8 \mathrm{~m}^{2} \mathrm{~kg}^{-1}$ (Taillandier et al., 2006), as the transformed melt-freeze crust, suggesting that the SSA of depth hoar is not affected by the initial nature of the snow. At present, we lack data to quantitatively evaluate the frequency of the transformation of melt -freeze layers into depth hoar or faceted crystals. However, melt-freeze layers are frequent in the Arctic. We have observed them in Northern Alaska and in Svalbard every spring that we were there. 
Regarding mid-latitudes, Birkeland (1998) reports that radiative heating can induce the formation of a melt layer a few $\mathrm{mm}$ below the snow surface. With this layer acting as a source of vapor, and elevated transient temperature gradients (up to $200^{\circ} \mathrm{C} \mathrm{m}^{-1}$, Birkeland et al., 1998) caused by diurnal temperature cycles, Birkeland observed the formation of thin layers of faceted crystals just above the melt layer. Even though Birkeland did not study the transformation of the melt layer after it froze, it appears likely that it could itself frequently transform into faceted crystals (K. W. Birkeland, personal communication, 2008) of higher SSA. Faceted crystals have a SSA in the range $8-45 \mathrm{~m}^{2} \mathrm{~kg}^{-1}$ (Domine et al., 2007a) so that we expect this transformation to increase SSA, in a manner similar to the case we observed. Birkeland's observations were in Southwestern Montana, but probably apply to many south facing slopes at mid-latitudes.

These Arctic and mid-latitude observations suggest that melt-freeze crusts of low SSA can transform into faceted crystals or depth hoar of higher SSA whenever large temperature gradients $\left(100\right.$ to $\left.200^{\circ} \mathrm{C} \mathrm{m}^{-1}\right)$ are present. This can happen frequently in the Arctic and subarctic due to low temperatures and thin snowpacks, or at mid-latitudes due to diurnal temperature cycling.

Melt-freeze crusts being thin, their SSA increase will have little effect on the snowpack's ability to store adsorbed chemicals. The most notable effect will be the increased permeability, from about $1 \times 10^{-10} \mathrm{~m}^{2}$ for refrozen layers (Albert and Perron, 2000) to $500 \times 10^{-10} \mathrm{~m}^{2}$ for depth hoar (Shimizu, 1970; Sturm, 1991). This transformation will therefore restore the ability of the underlying layers to exchange chemical compounds with the atmosphere.

Significant radiative effects are expected only if this transformation takes place at or very near the snow surface. We quantified this effect using the DISORT software (Stamnes et al., 1988) which assumes that snow is made of spheres. We used a lognormal size distribution for the spheres, diffuse light conditions, and considered the spectral range $300-2500 \mathrm{~nm}$. Transforming a $5 \mathrm{~mm}$-thick refrozen surface layer of SSA $=3.4 \mathrm{~m}^{2} \mathrm{~kg}^{-1}$ into snow having a SSA of $8.8 \mathrm{~m}^{2} \mathrm{~kg}^{-1}$ increases albedo by $1.2 \%$, from 0.776 to 0.788 , if the refrozen layer sits above a semi-infinite layer of SSA $=8.8 \mathrm{~m}^{2} \mathrm{~kg}^{-1}$.

The radiative forcing caused by this albedo increase is significant. Assuming a daily-averaged incoming solar flux of $200 \mathrm{~W} \mathrm{~m}^{-2}$, the forcing at the surface is then $2.4 \mathrm{~W} \mathrm{~m}^{-2}$, greater than the $1.66 \mathrm{~W} \mathrm{~m}^{-2}$ for the radiative forcing caused by the $\mathrm{CO}_{2}$ increase between 1750 and 2007 (IPCC, 2007). Furthermore, this $2.4 \mathrm{~W} \mathrm{~m}^{-2}$ forcing caused by snow has a stronger climatic effect than the same forcing by $\mathrm{CO}_{2}$, because its forcing efficacy, i.e. the temperature rise caused by that forcing over the temperature rise due to an equivalent forcing by $\mathrm{CO}_{2}$, is 3 times as large (Hansen et al., 2005).

\subsection{Effect of wind on SSA}

Here we find that wind action on Arctic snow that is 2 to 3 weeks old results in a SSA increase, because of a decrease in crystal size due to sublimation and because of fragmentation. Cabanes et al. (2002) observed that wind accelerated SSA decrease of fresh dendritic snow because of the disappearance by sublimation of small microstructures having a high SSA. From these limited observations, we speculate that the vigorous remobilization of snow by wind may form layers of SSA between 40 and $65 \mathrm{~m}^{2} \mathrm{~kg}^{-1}$. Therefore, the SSA of snow with high SSA will decrease, while that of snow with low SSA will increase.

At mid-latitudes where precipitation events are more frequent, we suggest that wind storms will often decrease SSA. In Polar Regions, where precipitation events are infrequent, we speculate that wind action will increase the SSA of surface snow at least in $50 \%$ of cases, resulting in albedo increases. This is consistent with Grenfell et al. (1994) and Liljequist (1956), who observed that snow albedo increased after wind storms in Antarctica.

In our example from Alert, we calculate again using DISORT that the replacement of both $1 \mathrm{~cm}$-thick surface layers with a twice as dense $1 \mathrm{~cm}$-thick layer of SSA=61 m $\mathrm{kg}^{-1}$ will increase albedo by $0.9 \%$, from 0.843 to 0.852 . Assumptions are as above, and surface layers sit above a windpack of $\mathrm{SSA}=15 \mathrm{~m}^{2} \mathrm{~kg}^{-1}$. If on the other hand, the new layer covers only $50 \%$ of the windpack and is then $2 \mathrm{~cm}$ thick, the albedo will decrease by $1.9 \%$ to 0.833 , because of the lower albedo of the exposed windpack. The radiative and climatic consequences of these effects cannot be neglected, as detailed in the previous section.

Regarding the effect on contaminants, it is clear that SSA changes of $30 \%$ in a thin surface layer will not produce major changes in the snowpack loading of adsorbed pollutants. However, for contaminants of moderate to low volatility, most of the contaminant in the (snow+boundary layer) system will be in the snow. Simple calculations, as done by Taillandier et al. (2006) show that increases in SSA from 40 to $60 \mathrm{~m}^{2} \mathrm{~kg}^{-1}$ for a $2 \mathrm{~cm}$-thick snow layer of density $200 \mathrm{~kg} \mathrm{~m}^{-3}$ can decrease its boundary layer concentration by 1 to $15 \%$, depending on its volatility.

Wind-pumping of small snow crystals into snow and the resulting SSA increase is a new process that requires additional observations to be confirmed. We also expect this to produce an albedo increase, as well as an enhanced uptake of chemicals.

\section{Other considerations}

Other processes not observed here could lead to SSA increases. If surface hoar $\left(\mathrm{SSA}=24-56 \mathrm{~m}^{2} \mathrm{~kg}^{-1}\right.$, Domine et al., 2007a) forms on an aged wind slab of SSA $=15 \mathrm{~m}^{2} \mathrm{~kg}^{-1}$, the SSA of the surface snow will increase. Likewise, fog de- 
position, as frequently observed at the top of the Greenland ice cap in summer (Bergin et al., 1995; Domine et al., 1995) might lead to an SSA increase. However, the SSA of deposited fog has not been measured. Diamond dust, i.e. hardly perceptible clear sky precipitation formed of very small crystals that probably have a SSA on the order of $300 \mathrm{~m}^{2} \mathrm{~kg}^{-1}$ (Walden et al., 2003), is also likely to produce an SSA increase, without the appearance of a new snow layer.

Surface hoar formation may explain observations by previous authors. Pirazzini (2004) observed that at Hell's Gate (coastal Antarctica), the snow albedo increased during the night between 1 and 2 December 1997, in the absence of precipitation and under clear sky conditions. Pirazzini does not report any snow observations, but we speculate that this was due to surface hoar deposition on aged snow. McGuffie and Henderson-Sellers (1985, and references therein) also interpret diurnal albedo hysteresis at Resolute $\left(75^{\circ} \mathrm{N}\right.$, Canadian Arctic) by the nighttime formation of surface hoar, with daytime sublimation.

In a global warming context, changes in snow albedo can exert powerful forcings and feedbacks (Jacobson, 2004; Hansen et al., 2005; Flanner and Zender, 2005; Flanner et al., 2007). It is therefore essential to understand the causes of observed changes in snow albedo. While the formation of snow crystals of higher SSA is a possibility, another one is the formation of snow with fewer absorbing impurities. For example, the deposition of clean surface hoar of SSA $=30 \mathrm{~m}^{2} \mathrm{~kg}^{-1}$ on recent snow of $\mathrm{SSA}=60 \mathrm{~m}^{2} \mathrm{~kg}^{-1}$ but with a high soot content can increase surface albedo. Changes in snow albedo cannot always be interpreted in terms of snow physics only. If the predictive, physically-based modeling of the evolution of snow albedo is sought, effects on both light scattering and absorption by snow must be understood. We then suggest that snow albedo, snow SSA and concentration of light absorbers be measured simultaneously to reach this understanding. Crystal shapes may also be studied, as these affect albedo (Neshyba et al., 2003; Picard et al., 2009).

Acknowledgements. The work in Alaska was partially supported by Chapman Chair funds, kindly supplied by Norbert Untersteiner. AST and FD thank the Geophysical Institute, University of Alaska Fairbanks, and W. R. Simpson for hosting them during this work. We thank Bill Hauer for proposing the LARS site for the Alaska study, and Hajo Eicken for the use of the cold rooms. The work at Alert was supported by a grant from the French Polar Institute (IPEV) to FD (MICHARC program). Jan Bottenheim and Peter Brickell provided logistical and technical assistance at Alert. We thank Yves Lejeune and colleagues at Centre d'Etude de la Neige - Météo France for access to their site at Col de Porte and for communicating their meteorological data. We thank Charlie Zender for helpful discussions on snow albedo. The albedo calculations using DISORT were kindly done by Jean-Charles Gallet.

Edited by: D. Hall

\section{References}

Akitaya, E.: Studies on depth hoar, Contributions from the Institute of Low Temperature Science, Ser. A, 26, 67 pp., 1974.

Albert, M. R. and Perron Jr., F. E.: Ice layer and surface crust permeability in a seasonal snow pack, Hydrol. Process., 14, 32073214, 2000.

Bergin, M. H., Jaffrezo, J.-L., Davidson, C. I., Dibb, J. E., Pandis, S. N., Hillamo, R., Maenhaut, W., Kuhns, H. D., and Makela, T.: The contribution of snow, fog, and dry deposition to the summer flux of anions and cations at Summit, Greenland, J. Geophys. Res., 100, 16 275-16288, 1995.

Birkeland, K.W.: Terminology and predominant processes associated with the formation of weak layers of near-surface faceted crystals in the mountain snowpack, Arctic Alpine Res., 30, 193199, 1998.

Birkeland, K. W., Johnson, R. F., and Schmidt, D. S.: Near-surface faceted crystals formed by diurnal recrystallization: a case study of weak layer formation in the mountain snowpack and ist contribution to snow avalanches, Arctic Alpine Res., 30, 200-204, 1998.

Cabanes, A., Legagneux, L., and Domine, F.: Evolution of the specific surface area and of crystal morphology of Arctic fresh snow during the ALERT 2000 campaign, Atmos. Environ. 36, 27672777, 2002.

Cabanes, A., Legagneux, L., and Domine, F.: Rate of evolution of the specific surface area of surface snow layers, Environ. Sci. Technol., 37, 661-666, 2003.

Cunningham, J. and Waddington, E. D.: Air flow and dry deposition of non-sea salt sulfate in polar firn: paleoclimatic implications, Atmos. Environ. A-Gen., 27, 2943-2956, 1993.

Daly, G. L. and Wania, F.: Simulating the influence of snow on the fate of organic compounds, Environ. Sci. Technol., 38, 41764186, 2004.

Domine, F., Thibert, E., Silvente, E., Legrand, M. and Jaffrezo, J.-L.: Determining past atmospheric $\mathrm{HCl}$ mixing ratios from ice core analyses, J. Atmos. Chem., 21, 165-186, 1995.

Domine, F., Cabanes, A., and Legagneux, L.: Structure, microphysics, and surface area of the Arctic snowpack near Alert during ALERT 2000, Atmos. Environ., 36, 2753-2765, 2002.

Domine, F., Sparapani, R., Ianniello, A., and Beine, H. J.: The origin of sea salt in snow on Arctic sea ice and in coastal regions, Atmos. Chem. Phys., 4, 2259-2271, 2004, http://www.atmos-chem-phys.net/4/2259/2004/.

Domine, F., Salvatori, R., Legagneux, L., Salzano, R., Fily, M., and Casacchia, R.: Correlation between the specific surface area and the short wave infrared (SWIR) reflectance of snow, Cold Reg. Sci. Technol., 46, 60-68, 2006.

Domine, F., Taillandier, A.-S., and Simpson, W. R.: A parameterization of the specific surface area of snow in models of snowpack evolution, based on 345 measurements, J. Geophys. Res., 112, F02031, doi:10.1029/2006JF000512, 2007a.

Domine, F., Cincinelli, A., Bonnaud, E., Martellini, T., and Picaud, S.: Adsorption of Phenanthrene on Natural Snow, Environ. Sci. Technol., 41, 6033-6038, 2007b.

Domine, F., Albert, M., Huthwelker, T., Jacobi, H.-W., Kokhanovsky, A. A., Lehning, M., Picard, G., and Simpson, W. R.: Snow physics as relevant to snow photochemistry, Atmos. Chem. Phys., 8, 171-208, 2008, http://www.atmos-chem-phys.net/8/171/2008/. 
Dye, D. G.: Variability and trends in the annual snow-cover cycle in northern hemisphere land areas, 1972-2000, Hydrol. Process. 16, 3065-3077, 2002.

Flanner, M. G. and. Zender, C. S: Snowpack Radiative Heating: Influence on Tibetan Plateau Climate, Geophys. Res. Lett., 32(6), L06501, doi:10.1029/2004GL022076, 2005.

Flanner, M. G. and Zender, C. S.: Linking snowpack microphysics and albedo evolution. J. Geophys. Res. 111, D12208, doi:10.1029/2005JD006834, 2006.

Flanner, M. G., Zender, C. S., Randerson, J. T., and Rasch, P. J.: Present-day climate forcing and response from black carbon in snow, J. Geophys. Res., 112, D11202, doi:10.1029/2006JD008003, 2007.

Grenfell, T. C., Warren, S. G., and Mullen, P. C.: Reflection of solar radiation by the Antarctic snow surface at ultraviolet, visible, and near-infrared wavelengths, J. Geophys. Res., 99, 18 669-18 684, 1994.

Hall, A.: The role of surface albedo feedback in climate, J. Climate, 17, 1550-1568, 2004.

Hanot, L. and Domine, F.: Evolution of the surface area of a snow layer, Environ. Sci. Technol., 33, 4250-4255, 1999.

Hansen, J., Sato, M., Ruedy, R., Nazarenko, L., Lacis, A., Schmidt, G. A., Russell, G., Aleinov, I., Bauer, M., Bauer, S., Bell, N., Cairns, B., Canuto, V., Chandler, M., Cheng, Y., Del Genio, A., Faluvegi, G., Fleming, E., Friend, A., Hall, T., Jackman, C., Kelley, M., Kiang, N., Koch, D., Lean, J., Lerner, J., Lo, K., Menon, S., Miller, R., Minnis, P., Novakov, T., Oinas, V., Perlwitz, J., Perlwitz, J., Rind, D., Romanou, A., Shindell, D., Stone, P., Sun, S., Tausnev, N., Thresher, D., Wielicki, B., Wong, T., Yao, M., and Zhang, S.: Efficacy of climate forcings, J. Geophys. Res. 110, D18104, doi:10.1029/2005JD005776, 2005.

Harder, S., Warren, S. G., and Charlson, R. J.: Sulfate in air and snow at the South Pole: Implications for transport and deposition at sites with low snow accumulation, J. Geophys. Res., 105(D18), 22 825-22 832, 2000.

Herbert, B. M. J., Halsall, C. J., Villa, S., Jones, K. C., and Kallenborn, R.: Rapid changes in PCB an OC pesticide concentrations in Arctic snow, Environ. Sci. Technol., 39, 2998-3005, 2005.

IPCC: Climate Change 2007: Synthesis report, Cambridge University Press, 73 pp., 2007.

Jacobson, M. Z.: Climate response of fossil fuel and biofuel soot, accounting for soot's feedback to snow and sea ice albedo and emissivity, J. Geophys. Res., 109, D21201, doi:10.1029/2004JD004945, 2004.

Kokhanovsky, A. A. and Zege E. P.: Scattering optics of snow, Appl. Optics, 43, 1589-1602, 2004.

Legagneux, L., Cabanes, A., and Domine, F.: Measurement of the Specific Surface Area of 176 Snow Samples Using Methane Adsorption at 77 K, J. Geophys. Res., 107(D17), 4335, doi:10.1029/2001JD001016, 2002.

Legagneux, L., Lauzier, T., Domine, F., Kuhs, W. F., Heinrichs, T., and Techmer, K.: Rate of decay of the specific surface area of snow during isothermal experiments and morphological changes studied by scanning electron microscopy, Can. J. Phys., 81, 459468, 2003

Legagneux, L., Taillandier, A.-S., and Domine, F.: Grain growth theories and the isothermal evolution of the specific surface area of snow, J. Appl. Phys., 95, 6175-6184, 2004.
Legagneux, L. and Domine, F.: A mean-field model of the isothermal metamorphism of dry snow, J. Geophys. Res, 110, F04011, doi:10.1029/2004JF000181, 2005.

Liljequist, G. H.: Energy exchange of an Antarctic snow-field, in Norwegian-British-Swedish Antarctic Expedition 1949-1952, Scientific results Norsk Polarinstitutt, Oslo, 2, 93-103, 1956.

Marbouty, D.: An experimental study of temperature gradient metamorphism, J. Glaciol., 26, 303-312, 1980.

McGuffie, K. and Henderson-Sellers, A.: The diurnal hysteresis of snow albedo, J. Glaciol., 31, 188-189, 1985.

Meyer, T., Lei, Y. D., and Wania, F.: Measuring the release of organic contaminants from melting snow under controlled conditions, Environ. Sci. Technol., 40, 3320-3326, doi: 10.1021/es060049q, 2006.

Neshyba, S. P., Grenfell, T. C., and Warren, S. G.: Representation of a nonspherical ice particle by a collection of independent spheres for scattering and absorption of radiation. 2. Hexagonal columns and plates, J. Geophys. Res., 108(D15), 4448, doi:10.1029/2002JD003302, 2003.

Picard, G., Arnaud, L., Domine, F., and Fily, M.: Determining snow specific surface area from near-infrared reflectance measurements: numerical study of the influence of grain shape, Cold Regions Sci. Technol., 56, 10-17, 2009.

Pielke, R. A., Liston, G. E., Chapman, W. L., and Robinson, D. A.: Actual and insolation-weighted northern hemisphere snow cover and sea ice between 1973-2002, Clim. Dynam., 22, 591-595, 2004.

Pirazzini, R.: Surface albedo measurements over Antarctic sites, J. Geophys. Res., 109, D20118, doi:10.1029/2004JD004617, 2004.

Shimizu, H.: Air Permeability of Deposited Snow, Low Temperature Science, Series A, 22, 1-32, 1970.

Sokratov, S. and Sato, A.: Wind propagation to snow observed in laboratory, Ann. Glaciol., 31, 427-433, 2000.

Stamnes, K., Tsay, S. C., Wiscombe, W., and Jayaweera, K.: Numerically stable algorithm for discrete-ordinate-method radiative transfer in multiple scattering and emitting layered media, Appl. Optics, 27, 2502-2509, 1998.

Stone, R. S., Dutton, E. G., Harris, J. M., and Longenecker, D.: Earlier spring snowmelt in northern Alaska as an indicator of climate change, J. Geophys. Res., 107(D10), 4089, doi:10.1029/2000JD000286, 2002.

Sturm, M.: The Role of Thermal Convection in Heat and Mass Transport in the Subarctic Snow Cover, CRREL report 91-19, 1-84, 1991.

Sturm, M., and Johnson, J.: Natural convection in the subarctic snow cover, J. Geophys. Res., 96, 11 657-11 671, 1991.

Sturm, M. and Benson, C. S.: Vapor transport, grain growth and depth hoar development in the subarctic snow, J. Glaciol., 43, 42-59, 1997.

Sturm, M. and Liston, G. E.: The snow cover on lakes of the Arctic coastal plan of Alaska, J. Glaciol., 49, 370-380, 2003.

Taillandier, A.-S., Domine, F., Simpson, W. R., Sturm, M., Douglas, T. A., and Severin, K.: Evolution of the Snow Area Index (SAI) of the subarctic snowpack in Central Alaska over a whole season. Consequences for the air to snow transfer of pollutants, Environ. Sci. Technol., 40, 7521-7527, 2006.

Taillandier, A.-S., Domine, F., Simpson, W. R., Sturm, M., and Douglas, T. A.: The rate of decrease of the specific surface area of dry snow: isothermal versus temperature gradient conditions, 
J. Geophys. Res., 112, F03003, doi:10.1029/2006JF000514, 2007.

Waddington, E. D., Cunningham, J., and Harder, S.: The effects of snow ventilation on chemical concentrations, in: Chemical Exchange Between the Atmosphere and Polar Snow, edited by: Wolff, E. W. and Bales, R. C., Springer, 403-451, 1996.
Walden, V. P., Warren, S. G., and Tuttle, E.: Atmospheric ice crystals over the Antarctic plateau in winter, J. Appl. Meteorol., 42, 1391-1405, 2003.

Wania, F., Hoff, J. T., Jia, C. Q., and Mackay, D.: The effects of snow and ice on the environmental behaviour of hydrophobic organic chemicals, Environ. Pollut., 102, 25-41, 1998.

Warren, S. G.: Optical properties of snow, Rev. Geophys. Space Ge., 20, 67-89, 1982. 